\title{
University Bean Collection in the Prospect of Nutritional Research
}

\author{
Aytasheva ZG*, Zhumabaeva BA, Dzhangalina ED and Lebedeva LP \\ Department of molecular biology and genetics, Kazakhstan
}

ISSN: 2640-9208

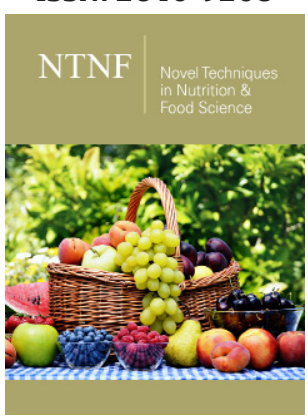

For HTML Version scan this QR code:

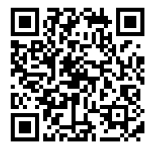

${ }^{* 1}$ Corresponding author: Aytasheva ZG, Department of molecular biology and genetics, Kazakhstan

Submission: 留 February 01, 2019

Published: : March 12, 2019

Volume 3 - Issue 4

How to cite this article: Aytasheva ZG*, Zhumabaeva BA, Dzhangalina ED and Lebedeva LP. University Bean Collection in the Prospect of Nutritional Research. Nov Tech Nutri Food Sci. 3(4). NTNF.000567.2019.

DOI: 10.31031/NTNF.2019.03.000567

Copyright@ Aytasheva ZG, This article is distributed under the terms of the Creative Commons Attribution 4.0 International License, which permits unrestricted use and redistribution provided that the original author and source are credited.

\begin{abstract}
Current experimental program has been carried out in order to determine the outputs of crop rotation in mountain and steppe areas in the outskirts of Almaty. The main morphogenetic characters have been studied by implying the collection of common beans, Phaseolus vulgaris $\mathrm{L}$ composed of several samples from such countries as Kazakhstan, China, Czech Republic, Poland, Turkey, Russia and USA, generated under different climate and soil conditions. A series of useful genetic resources displaying major economically valuable traits were identified. Several introduced cultivars of common bean have revealed proper seed emergence rate, suitable maturation and significant resistance to the water scarcity $[1,2]$. Some Kazakhstani varieties have been shown to surpass foreign specimens and cultivars by the seed weight and other parameters. It has been indicated that cv. "Luna" from Czech collection would get maturation the first ( 80 days from planting to complete technical maturity), whereas the rest of cultivars have been recorded to rich the same conditions a decade later [3]. Local specimen "Aktatti" has manifested its response to the effect of new bio-organic mineral fertilizer synthesized by the Faculty of Chemistry [4]. Basic catalogue of common bean resources including approximately 40 parental cultivars and accessions of Phaseolus vulgaris $\mathrm{L}$ and their relatives originally from different geographic regions has been compiled [5].
\end{abstract}

The data have been completed by quantitative and qualitative amino acid analysis. Kazakhstani and external cultivars and specimens respectively have been subdivided by the data on amino acid composition of seeds further tested by liquid chromatography. Essential amino acids have been determined to set up approximately $30 \%$ of the total content of amino acids among Kazakhstani specimens [6]. If tyrosination index (Phe/Tyr ratio) for external varieties was equal to $0.88-0.89$, local specimens have shown the similar index to be around 0.90-0.95. This difference may emphasize the role of powerful membrane proteins in strengthening domestic lines by a composite stability (resilience, temperature and metabolic) when compared to international common bean specimens under investigation [7]. Following research on domestic bean collection in terms of the application of another developing branches of bean biology and biotechnology is considered to require special attention of researchers and authorities in charge [8].

Keywords: Common bean; Cultivar; Catalogue of stock resources; Amino acid composition

\section{Introduction}

Summarizing the list of the most studied medical effects caused by the common bean it is noteworthy to mention its usefulness as: antidiabetic food, activator of the alimentary tract, positive regulator of cardiovascular network, the skin signifier, relieving food additive for the fatigue, mitigating additive for the rheumatoid arthritis symptoms, cold treating substance, preventing agent of Alzheimer's disease, bones fortifier, anti-aging effector, the agent against cataract [9-12]. Contraindications to the use of the common bean concern patients with gastritis, cholecystitis, pancreatitis, high acidity, ulcer, colitis, and gout. Seeds of 17 cultivars and specimens of Phaseolus vulgaris $L$ were sown in the mountains [13-15]. 20 cultivars and lines of common bean and its relatives (broad bean, Vicia faba L. and Turkish beans, Phaseolus coccineus L.) were planted in the steppe zone. Experiments were focused on percentage of emergence, length of pods and the content of amino acids in seeds. For this purpose, the method of liquid chromatography was used. To increase germination, we introduced $25-30 \mathrm{~g}$ of domestic bioorganic fertilized per plot 25-35 days after planting with moderate watering [16].

Judging by the studies fulfilled, "Nazym" specimen has been attributed to a unique line demonstrating unique morphogenetic characters. By quantities of few amino acids (Glu, 
Asp, Ala, and Pro) local bean samples have been shown to outstrip external cultivars more than two times [17]. The unique features of local bean specimen "Nazym" was confirmed by computational estimation of essential amino acids. Current progress in bean biology and biotechnology may be explained by growing diversification of this research area. Major trends could be classified as shown in Table 1.

Table 1: List of research trends in common bean biology and biotechnology.

\begin{tabular}{|c|c|c|}
\hline No & Research Direction & Citation(s) \\
\hline 1 & Bean domestication history, studies on orphan (under-utilized) legumes & $\begin{array}{c}\text { Berrocal-Ibarra et al. [1] } \\
\text { Cullis and Kunert [2] } \\
\text { Kwak et al. [3] } \\
\text { Lopez Herrera et al. [4] } \\
\text { Nanni et al. [5] } \\
\text { Peña-Valdivia et al. [6] }\end{array}$ \\
\hline 2 & Bean plant physiology and biochemistry, food legume productivity research, & $\begin{array}{c}\text { Daryanto et al. [7] } \\
\text { Hyman et al. [8] }\end{array}$ \\
\hline 3 & combined studies on dryland cereals and legumes & Varão Vasconcelos et al. [9] \\
\hline 4 & Bean genetics and chromosome biology & $\begin{array}{c}\text { Hiz MC et al. [10] } \\
\text { Kavas et al. [11] }\end{array}$ \\
\hline 5 & Bean molecular biology, bean RNA biology & Silva Lamas et al. [12] \\
\hline 6 & Bean virology, genomoviral studies & Ballhorn et al. [13] \\
\hline 7 & Bean pathology, bean symbiotic studies & Marcenaro D \& Valkonen JPT [14] \\
\hline 8 & Bean metabolic engineering, bean biofortification & Ramirez Rivera et al. [15] \\
\hline 9 & Bean diet research, bean nutrigenetics and nutrigenomics & Gómez 0jeda et al. [16] \\
\hline
\end{tabular}

\section{Conclusion}

Analysis of morphogenetic traits across different accessions has allowed to compile the basic catalogue of original P. vulgaris cultivars and lines. It includes more than 40 parental specimens and their relatives of different origin. Local line "Nazym" has appeared to be quite promising to be grown commercially in SouthEast regions of Kazakhstan for ornamental and nutritional aims. This line is also referred to be advanced by the essential amino acids content, surpassing the reference cultivars and lines under investigation. Further development of domestic bean collection for the application to another directions of bean biology and biotechnology is regarded to need joint efforts of researchers and authorities in charge.

\section{References}

1. Ibarra SB, Cereceres JO, Valdivia CBP, Botha FC (2002) Yield components, harvest index and leaf area efficiency of a sample of a wild population and a domesticated variant of the common bean Phaseolus vulgaris. South African Journal of Botany 68: 205-211.

2. Cullis C, Kunert KJ (2016) Unlocking the potential of orphan legumes. J Exp Bot 68(8): 1895-1903.

3. Kwak M, Toro O, Debouck DG, Gepts P (2012) Multiple origins of the determinate growth habit in domesticated common bean (Phaseolus vulgaris). Annals of Botany 110 (8): 1573-1580.

4. Herrera ML, Rivera JRA, Trejo C, Valdivia CBP (2001) Differences in seed germination of wild and domesticated common bean (Phaseolus vulgaris $L$ ) in response to storage. South African Journal of Botany 67(4): 620628.

5. Nanni L, Bitocchi E, Bellucci E, Rossi M, Rau D, et al. (2011) Nucleotide diversity of a genomic sequence similar to SHATTERPROOF (PvSHP1) in domesticated and wild common bean (Phaseolus vulgaris $\mathrm{L}$ ). Theor Appl Genet 123(8): 1341-1357.
6. Valdivia CBP, Urdaneta ABS, Rangel JM, Muñoz JJ, Nava IRG, et al. (2010) Anatomical root variations in response to water deficit: wild and domesticated common bean (Phaseolus vulgaris L). Biol Res 43(4): 417427.

7. Daryanto S, Wang L, Jacinthe PA (2015) Global synthesis of drought effects on food legume production. PLoS One 10(6): e0127401.

8. Hyman G, Barona E, Biradar C, Guevara E, Dixon J, et al. (2016) Priority regions for research on dryland cereals and legumes. Version 2 F1000Res 5: 885 .

9. Vasconcelos EV, Fonsêca AFA, Harand AP, Bortoleti KCA, Iseppon AMB, et al. (2015) Intra and intrachromosomal rearrangements between cowpea (Vigna unguiculata (L.) Walp.) and common bean (Phaseolus vulgaris $L$.) revealed by BAC -FISH. Chromosome Res 23: 253-266.

10. Hiz MC, Canher B, Niron H, Turet M (2014) Transcriptome analysis of salt tolerant common bean (Phaseolus vulgaris $L$ ) under saline conditions. PLoS One 9(3): e92598.

11. Kavas M, Baloglu MC, Atabay ES, Ziplar UT, Dasëgan HY, et al. (2016) Genome-wide characterization and expression analysis of common bean bHLH transcription factors in response to excess salt concentration. Mol Genet Genomics 291(1): 129-143.

12. Lamas NS, Fontenele RS, Melo FL, Costa AF, Varsani A, et al. (2016) Complete genome sequence of a genomovirus associated with common bean plant leaves in Brazil. Genome Announc 4(6): e01247-16.

13. Ballhorn DJ, Schädler M, Elias JD, Millar JA, Kautz S (2016) Friend or foelight availability determines the relationship between mycorrhizal fungi, rhizobia and lima bean (phaseolus lunatus l). PLoS One 11(5): e0154116.

14. Marcenaro D, Valkonen JPT (2016) Seedborne pathogenic fungi in common bean (Phaseolus vulgaris cv. INTA Rojo) in nicaragua. PLoS One 11(12): e0168662.

15. Rivera NGR, Salinas CG, Aragao FJL, Garza RID (2016) Metabolic engineering of folate and its precursors in Mexican common bean (Phaseolus vulgaris L). Plant Biotechnol J 14(10): 2021-2032.

16. Gómez 0, Wrobel K, Escobosa ARC, Elguera JCT, Sevilla EG (2015) Molybdenum and copper in four varieties of common bean (phaseolus 
vulgaris) new data of potential utility in designing healthy diet for diabetic patients. Biol Trace Elem Res 163(1-2): 244-254.
1. Zhang S, Wei J, Kang L (2012) Transcriptional analysis of Arabidopsis thaliana response to lima bean volatiles. PLoS One 7(4): e35867..

For possible submissions Click below: 